\title{
THE SUPPLEMENTARY PROTECTION CERTIFICATE: THE RECENT DECISIONS OF THE COURT OF JUSTICE OF THE EUROPEAN UNION
}

\begin{abstract}
In recent years, public health systems in high-income countries have been heavily exposed to pressures due to high drug prices. High drug prices are affected by market monopolies that pharmaceutical companies have thanks to patents, i.e. the exclusive rights granted to them for drugs. An additional factor affecting high drug prices is the extended forms of intellectual property protection, including the extension of the exclusivity period after the expiration of a patent for medical devices. The supplementary protection certificate as a form of a supplementary protection for pharmaceutical products in the European Union is regulated by the Regulation 469/2009. This form of protection is also known in the national patent regulations. Since the entry into force of the Regulation 469/2009, there has been debated the question of whether the supplementary protection certificate should be available for new therapeutic uses of previously approved active ingredients. In addition, the subject of interpretation was also the Article 3(a) of the Regulation 469/2009 requiring that the "product" (i.e. the active ingredient or combination of active ingredients) being the subject matter of the SPC application, should be "protected by the basic patent".
\end{abstract}

\footnotetext{
${ }^{*}$ LLD, Associate Professor at the Faculty of Law, The University of Kragujevac, Serbia, e-mail: slucic@jura.kg.ac.rs

(c) () (C) 2021 by the authors. This article is an open access article distributed under the terms and conditions of the Creative Commons Attribution (CC BY) license (https://creativecommons. org/licenses/by/4.0/).
} 
The author analyzes several important decisions of the EU Court of Justice, with an emphasis put on the recent verdicts in both the "Santen" and "Royality Pharma" cases. In the grounds of these cases, there have widely been discussed the issue concerning the encouragements given to pharmaceutical companies being involved into medical researches in order to stimulate their investment into innovation treatments.

\section{Keywords: patents, additional protection, pharmaceutical products}

\section{Introduction}

The patent is the right to the intellectual property which gives the inventor the exclusive right to production, distribution, import and use of the invention protected by the patent (Lasić, 2014, p. 178). The patent is valid for 20 years since the day of submitting the patent application, which means that the competition to the patent's inventor is prevented from economic exploitation of the invention protected by the patent. This is understandable and justifiable, bearing in mind for example great expenses which pharmaceutical companies invest in the research and development of the new medicine (Marković, 2016, p. 33). The expenses in question are especially present in the areas which are not sufficiently discovered, as for example are rare diseases. In order to be protected by the patent the invention must be new, possess a certain inventive level and must be appropriate for the industrial application. These conditions apply also to all the inventions which are protected by a patent. However, the patent protection of the pharmaceutical inventions is to a great extent specific. Namely, in the past decades the expenses for research and development in the innovative pharmaceutical industry have risen greatly. The main reason lies in the fact that the procedure for allowing the medicine to be put into circulation is long, strict and complicated (Marković, 2016, p. 34). Before getting a permission to put the medicine into circulation and distribution, many research are carried out in order to prove if a certain medicine is safe and efficient in the treatment of the certain disease (Killick \& Schultz, 2008, p. 3).

On average, there may pass 13 years from the day of the submission of the patent application till obtaining the permit to put the medicine into circulation. That is the main reason why the pharmaceutical companies submit the patent application in the early stage of the medicine research and development. The research and development of the medicine, is continued, even after submitting the patent application (Fachler, 2014, p. 1062). Bearing in mind that till the medicine is permitted to be used (the research of the medicine, 
the submitting and investigating the patent application, the clinical medical testing), there isn't much time left for the commercialization of the medicine ( 7 years on average). That means that the rest of time is devoted by the pharmaceutical companies to return the investment and make profit, which in turn, may enable further research and the development of the new medicines. For that reason the pharmaceutical industry would need the possibility of the deadline extension of the validity of the patent protection. This was made possible by the introduction of certificates of the additional protection into the patent system. The paper will further discuss this form of the additional protection for the invention of the pharmaceutical products. A special emphasis will be placed on the court practice in EU Court of Justice about the additional protection for the second medical use. This question has especially become an important issue after the recent verdict of the Court of Justice in the "Santen case" which has brought about different comments both by the experts and also by the pharmaceutical products manufacturers.

\section{Supplementary protection certificate - general characteristics}

Supplementary protection certificate (SPC in further text) is sui generis the intellectual property right which begins with the expiration of the basic patent (Kalden, 2015, p. 98). The protection which is recognized by the certificate refers to the medicines for human or animal use for means for the protection of plants which require the permission in order to be put to circulation and which were previously protected by the patent. There are products which are protected by the patent and which are under the jurisdiction of being approved in order to be put into circulation, but which cannot be the subject of SPC. For example, medical devices and auxiliary means in the medicine reinforce the therapeutic effect, do not possess the direct therapeutic effect for the approved indication, and thus cannot be the matter of the SPC protection (e.g. the auxiliary means in the vaccine).

SPC has a great significance. Namely, there is an opinion that up to $80 \%$ of income obtained by the pharmaceutical companies could be generated during the period of the validity of SPC (Kalden, 2015, p. 99). This right makes up for the loss in the effective validity of the patent to the carriers of the project. This loss refers to the time necessary for obtaining the permission for the putting the medicine into circulation which is protected by the patent.

SPC is recognized in all the EU countries (Bently \& Sherman, 2002, p. 54). Apart from that, this kind of protection is recognized by countries which 
are not members of the EU, but which are encompassed by the European patent application. In Serbia is regulated by the Law on patents.

The protection which is recognized by the certificate is limited to the products protected by the patent, and for the approval of which to be put to circulation the permission of the state body in charge is necessary. Furthermore, the certificate provides the protection for that product in the same scope as the patent on which the certificate is based. In other words, SPC refers only to the medical use encompassed by the patent protection.

The request for the recognition of SPC is submitted to the national institute for patents. When it comes to Serbia, the body in charge for the submission of this request is The Institute of the Intellectual property. The request for the recognition of SPC can only be submitted by the owner of the original patent, and within six month from the day from the date of the issuance of the permit for putting the product protected by the original patent into use. Exclusively, if the permit for putting into use was issued before the recognition of the patent, the request for the recognition of SPC can be submitted within 6 month from the date of the patent recognition.

The conditions for the recognition of the certificate which is prescribed by the Law on patent of the Republic of Serbia are aligned with the European Regulation 469/2009, as well as the Regulation no. 2019/933. Namely, SPC is recognized if the following conditions have been fulfilled:

- the product is protected by the original patent which is in force.

- the permit for putting the product as medicine into use has been issued

- the product was not previously the subject of the protection by certificate

- the permit to be put into use must be the first permit.

At first sight each of these condition which are prescribed by the Law on patents under the Act 116, and EU regulation no. 469/2009 together with Act 3 can easily be fulfilled. However, each of these conditions was the subject of the multiple interpretations of The Court of Justice of the EU.

\section{The first approval of putting the product on the market as the medical product}

One of the requirements for the recognition of the certificate for the additional protection which in practice has brought about numerous dilemmas and called for interpretation is "the first approval for putting the product on the market as the medical product" itself.

The attepts in the foreign court practice to broadly interpret this requirement were put to a stop by the verdict of the Court of Justice in the case 
C-31/03. ${ }^{1}$ In this verdict the EU Court of Justice has pointed out that granting the SPC to the Union member state based on the medical product for the human use permitted in that member state is annulled by the permission to put that product for the human use permitted in that member state is annulled by the permission to put that product on the market as veterinarian-medical product which was issued in the other state member prior to the stated date in Art. 19 (1) Regulation no. 1768/92. Thus, the standpoint of the court practice was that SPC for other or further medical useo $f$ the know active ingredients is not allowed. However, it was often stated that this court practice is opposite to the basic aims of the SPC Regulation, i.e. to "ensure the sufficient protection for stimulating the pharmaceutical research".

The things have, however, changed by bringing the verdict "Neurim" in the case $\mathrm{C}-130 / 11 .^{2}$ In contrast with the previous court practice, which was considered as anti-patent, this verdict lead to the liberalization of the SPC recognition. It represented the encouragement to the companies to take part in the research of the new useo $f$ the previously approved active ingredients.

Namely, the company Neurim has undertaken the research on melatonin, the natural hormone which was not the subject of the patent. The research result was that certain melatonin formulation can be used as an insomnia medicine. In the meantime, the ecompany Neurim was granted the European patent for the discovered melatonin formulation which was applied in the medicine for human use under the name of "Circadin". After Neurim got a permission to put the medicine into circulation, it requested the SPC recognition, because the patent permission to put the medicine into circulation, it requested SPC recognition, because the patent which protected that new medicine had less than five years before the protection expiry. Nevertheless, The British Institute for Intellectual Property declined to grant SPC to Neurim for the patented formulation of the melatonin for the use in sleeping treatment by the oral application of "Circadin" medicine.

The ground for refusal to recognize SPC was the fact that no matter if "Circadin" was the subject of the original patent in force, there had been a prior approval of putting into circulation by the third party for a different formulation of melatonin called Regulin- the regulation of the reproductive capacity in sheep. Regulin was protected by the patent on behalf of the company

\footnotetext{
${ }^{1}$ C- 31/03 Pharmacia Italia, Downloaded 2021, May 15 from https://curia.europa.eu/juris/liste. jsf? \&num=C-31/03.

${ }^{2}$ C-130/11 Neurim, Downloaded 2021, May 15 from https://curia.europa.eu/juris/liste. jsf?num $=\mathrm{C}-130 / 11 \&$ language $=\mathrm{EN}$.
} 
Hoechst and ceased to exist in 2007. So the request to grant SPC for Circadin medicine was declined due to the fact that the request for the permit to put into circulation Circadin was not the first permit which referred to melatonin. The original approval/permit referred to the veterinarian, and the subsequent permit to the humane application/use.

Being unsatisfied by the result of the decision Neurim Company filed a suit and the dispute eventually ended up at the Court of Justice of EU. This Court brought the verdict in favour of Neurim. Namely, the court stand point was that "... the mere existence of an earlier marketing authorisation obtained for a veterinary medicinal product does not preclude the grant of a supplementary protection certificate for a different application of the same product for which a marketing authorisation has been granted, provided that the application is within the limits of the protection conferred by the basic patent relied upon for the purposes of the application for the supplementary protection certificate".

The pharmaceutical and agrochemical companies greeted the verdict with enthusiasm. However, the verdict, i.e. the notion of "new use" to which Neurim refers to opened some new questions. For example, what about the therapeutical indications for different diseases or with the new dosages?

At the beginning of 2019 the Court of Justice EU brought a verdict which to a great extent disappointed the pharmaceutical industry. Namely, after the "Neurim" verdict the pharmaceutical industry continued with significant investment into research and development of the new formulas which improve the efficiency of the previously approved active ingredients or their combinations. However, in the new verdict "Abraxis" in the case C-443/17 the Court was of the opinion that SPC cannot be obtained for the new formulations of the previously approved active ingredients. ${ }^{3}$

Abraxis is a pharmaceutical company which produces, i.e. puts into circulation a medicine Abraxane ${ }^{\circledR}$ used in cancer treatment. This medicine contains the substance paclitaxel which is made of nano-particles of the paclitaxel connected to the albumin. This active substance, called nab-paclitaxel, was protected by the company Abraxis with the use of the European patent and got the permission to put into circulation the medicine Abraxane ${ }^{\circledR}$; the permission was obtained by the European Medicines Agency. In addition, it was proven that adding the albumin gives the nab-paclitaxel greater efficiency. In the meantime, the company submitted the request for the SPC. However,

\footnotetext{
${ }^{3}$ C-443/17 Abraxis Bioscience, Downloaded 2021, May 12 from https://curia.europa.eu/juris/ liste.jsf?language $=$ en $\&$ jur $=\mathrm{C}, \mathrm{T}, \mathrm{F} \&$ num $=\mathrm{C}-443 / 17 \& \mathrm{td}=\mathrm{ALL}$.
} 
before the Abraxis got the permission to put into circulation the medicine Abraxane ${ }^{\circledR}$, other companies had put into circulation the active substance paclitaxel. The request for SPC was denied with the explanation Regulation 469/2009 in Art. 38(c) allows the granting of SPC for the new an innovative therapeutic application of an old active substance, but not the allocation of SPC for the new and innovative formula of that substance.

Undoubtedly Abraxis company has undertaken a lengthy and expensive research for the development Abraxane ${ }^{\circledR}$, as well as that it required a lot of time to obtain the permit to put the medicine into circulation. Also, this company was of the opinion that nab-paclitaxel should be considered as an active ingredient. However, this opinion was rejected with the explanation that paclitaxel is an active ingredient and albumin a carrier. Yet, in its decision the EU Court of Justice has drawn a parallel between this and its prior decision in the case of C-210/13. ${ }^{4}$ This case refers to the dilemma, whether the adjuvant of the vaccine can be considered as an active ingredient in the circumstances when the adjuvant itself did not possess the therapeutical effect, i.e. did not provide any immunity, whether against the influenza (flu) or any other disease. The court was of the opinion that the reasoning for excluding such auxiliary means from the meaning of the "product" is applied to the same extent to the exclusion of the bearer, such as is albumin, even if it is permitted for the active ingredient with which it is connected in order to perform more efficiently its therapeutical effect. The Court, also, considered this conclusion not to change the fact that although the active ingredient and the carrier are connected together in the form of nano particles, since nano particles cannot be considered as the "product" which is different from the "product" which solely consists of the active ingredient (i.e. paclitaxel). Thus, the Court was of the opinion that SPC cannot be granted for the new formulation of the previously approved product, i.e. old active substances.

In the latest verdict "Santen" in the case of C-673/18 the EU Court of Justice had to deal with the question, whether SPC which represents the award for the pharmaceutical innovation refers only to the discovery and development of the completely new active substances or the pharmaceutical companies can deal with the research about the new treatments, including the new applications of the old ingredients. ${ }^{5}$

\footnotetext{
${ }^{4}$ C-210/13 Glaxosmithline, Downloaded 2021, May 15 from https://curia.europa.eu/juris/liste. jsf?num=C-210/13.

${ }^{5}$ C-673/18 Santen, Downloaded 2021, May 15 from https://curia.europa.eu/juris/liste.jsf?langua $\mathrm{ge}=\mathrm{en} \& \mathrm{td}=\mathrm{ALL} \&$ num $=\mathrm{C}-673 / 18$.
} 
The Japanese pharmaceutical company Santen, which specializes in ophthalmology, is the carrier of the European patent which protects the ophthalmological emulsion. The active ingredient of this emulsion is cyclosporine. The Santen Company had the permit to put into the circulation the medicine "Ikervis" which is used in the treatment of the grave keratitis. In the meantime, the Santen Company submitted the request for SPC to be granted for the product under the name of "the Cyclosporine for the use in the treatment of keratitis". However, the request was rejected with the explanation that the permission to put the cyclosporine into circulation is not the first permit in the sense of the Regulation e 469/2009. Namely, the previously issued permit to put into the circulation the medicine called "Sandimmun" which also contains the active ingredient cyclosporine, and which issued to threat uveitis. The dispute reached the Court of Justice EU. As different from the "Neurim" case, in the case of "Santen" the Court started to investigate the meaning of the notion "the product". In that sense, the Court first considered if the new therapeutical application of the active ingredient can be considered as the product which differs from the other already known application of the active ingredient.

It then considered whether the permit to put into circulation with the approval for the new therapeutical application of the active ingredient can be considered as the first permit in the sense of Art. 3 (d) of the Regulation 469/2009.

The Court finally completely declined in its verdict the conclusions stated in "Neurim" verdict and opted for the strict interpretation of the "product" from the Regulation 469/2009. The Court concluded that this narrower interpretation fulfills one of the goals of the Regulation 469/2009, and it is the balance between the encouraging the pharmaceutical research and the public health interests. The Court has in its decision also taken into consideration the fact that the broader interpretation endanger the simplicity of the SPC system and lead to different decisions of the National patent institutions.

\section{Product protected by a basic patent: case Royality Pharma}

One of the conditions for obtaining the SPC is that the product "is protected by a basic patent in force". The CJEU had the opportunity to assess this criterion in the Teva case (C 121/17). ${ }^{6}$ The company Gilead had the SPC for the Truvada product, which it contains tenofovir disproxil (TD) and

\footnotetext{
${ }^{6}$ C-121/17 Teva, Downloaded 2021, June 11 from https://curia.europa.eu/juris/liste.jsf?language $=$ en\&td $=$ ALL\&num $=\mathrm{C}-121 / 17$.
} 
emtricitabine. Claim 27 of the basic patent claimed TD "and optionally other therapeutic ingredients". A dispute arose as to whether this request covered the combination of TD and emtricitabine. The CJEU answered this question in its decision, namely... "the combination of the active ingredients must necessarily, in light of the description and drawings of that patent, fall under the invention covered by that patent; and each of those active ingredients must be specifically identifiable, in light of all the information disclosed by that patent". However, some questions remained unanswered. For example, the Court did not answer the question whether this test applies to single as well as combination products. Besides, the CJEU did not clarify whether the product must reflect the core inventive advance of the basic patent.

The CJEU pointed out in its decision that the product must be specifically identifiable by the person skilled in the art in light of the description and drawings of the patent, and "the prior art as at filing date or the priority date of that patent". However, it remained unclear whether the court meant that the skilled person's relevant knowledge is the "common general knowledge", rather than the prior art or a combination of both. This issue is left to the national courts to interpret. As expected, the national courts had different results in applying the Teva decision. The CJEU was nevertheless given a new opportunity to rectify the shortcomings of the Teva decision in the Royality Pharma case.

In the first half of last year, the Court of Justice of the European Union delivered its judgment in Case C-650/17, Royalty Pharma. ${ }^{7}$ The case was referred to the CJEU by the German Federal Patent Court. This court requested the interpretation of Article 3(a) of the Regulation 469/2009. The contentious issue was whether an active ingredient that is neither expressly mentioned in the claims nor specifically mentioned in the patent, but which is covered by the functional definition in the claims of that patent, is protected on the basis of Article 3(a) of Regulation No. 469/2009/EC, even if that product was developed only after the filing date of the patent as a result of an independent inventive step.

The pharmaceutical company, Royality Pharma, requested SPC for sitagliptin on the basis of the basic patent and of an authorisation to place a medicinal product on the market for the diabetes product "Januvia". The German Patent Office refused to recognize due to failure to comply with Article 3 (a) of the Regulation. Namely, sitagliptin was developed by a licensee of the basic patent after the date on which the application for that patent was filed. The

${ }^{7}$ C-650/17 Royalty Pharma, Downloaded 2021, June 22 from https://curia.europa.eu/juris/liste. jsf?num $=\mathrm{C}-650 / 17$ \&language $=\mathrm{en}$. 
licensee obtained a new patent for sitagliptin, which served as the basic patent for obtaining the SPC.

Sitagliptin is developed after the date on which the application for basic patent. This active ingredient is neither expressly mentioned in the claims nor provided as a concrete embodiment in the basic patent. Meanwhile, the CJEU has ruled in the case C-121/17, Teva. As stated above, it was the first SPC judgment rendered by the CJEU and was supposed to set a final standard for the assessment of the contentious Article 3(a) of the Regulation.

Even before Teva's decision, there were differences among the EU Member States in their interpretations of the criteria developed in the caselaw of the CJEU on Article 3(a) of the Regulation. However, even in Teva's decision, the CJEU did not specifically address the issue, whether or not the core inventive advance of the basic patent should be taken into account when evaluating whether an active ingredient is protected by the basic patent under Article 3(a) of the Regulation.

In the latest decision (case Royality Pharma), the CJEU took the position that a product that is the subject of the SPC and that was developed after the application for a basic patent after an "independent invention step" cannot be covered by a basic patent even if it falls under the functional definition in patent claims. However, the ECJ did not provide guidance on what constitutes an "independent inventive step".

The significance of the decision of the CJEU in case C-650/17 is reflected in the fact that the court provided clarification regarding the test of "basic invention progress", as well as regarding the relevant date for assessing whether the product is protected by the basic patent. This clarification could be important in aligning relevant future decisions of national courts and authorities. Namely, the court confirmed in the analyzed decision that while an SPC must be limited to the technical characteristics of the invention protected by the basic patent, there is no requirement that SPC applicants must overcome a "core inventive advance" test to meet the criteria for eligibility, thereby finally rejecting this principle regarding Article 3(a).

\section{Conclusion}

SPC exists with the aim of prolonging the validity of the patent. In the greatest number of countries the patent lasts for twenty years. However, the patents also protect the products for which the permission to be put to circulation the permit by the body in charge is necessary. It happens so that this permit is obtained a few years before the expiration of the patent, thus SPC 
prolongs the validity of the patent to the maximum of five years. Otherwise the companies would be de-stimulated to invest into the research of such products. The regulations about SPC have aroused dilemmas among the legal and pharmaceutical experts and required the interpretation of the institutions in charge. Even a few times have the regulations concerning SPC changed.

The dilemmas were present among the legal experts and the manufacturers of the pharmaceutical products about the interpretation of Art. 3(d) of the Regulation 469/2009. By a number court decisions the EU Court of Justice brought at the end of 2011 it was expected that the longer period in which circumstances SPC can be granted aimed at the combined products. Namely, the decision Neurim which refers to the protection of SPC for the second, i.e. further medical application expanded the possible circumstances under which this protection is accessible. The decision seemed to be taken as a guideline by the national courts and they perceived its interpretation according to their liking. However, the veredict in the case of Santen The Court has rejected its previous verdict in the case of Neurim and opted for the literal interpretation of the Regulation 469/2009. According to this interpretation SPC can not be allocated for the new applications of the previously approved products. In other words, SPC cannot be granted to the products for other medical use. However, the concern has arisen due to this verdict among the legal experts, and especially the pharmaceutical companies in the sense that it can de-stimulate the research of the new applications of the existing pharmaceutical products.

However, the good side of this verdict is that the EU Court of Justice has lined clear guidelines in it for the interpretation of Art. 3(d) of the Regulation 469/2009. Before this verdict the courts and patent institutions had an unclear approach concerning the granting of SPC for other medical use. The example for this is the decision of the Supreme Court of Great Britain from 2018 in the case Warner-Lambert\&Actavis/Mylan which caused the insecurity in the manner of application of other medical use. However, the current decision about SPC will to a great extent contribute to the harmonization of regulations of SPC on the national level.

The court decision in the case of "Santen" is not very surprising bearing in mind the pressure which has been made in the recent years on the health care systems of certain European countries due to the high medicine prices (Hu, Eynikel, Boulet \& Krikorian, 2020, p. 3). As the main reason of the high prices of medicines is most often stated the monopole which the pharmaceutical companies have thanks to the patents and the possibility for the extension of the patent validity period, which refer to medicines. Especially, at the same 
time, the extension of the validity period is recognized as the reason because of which the medicines are not accessible to all the patients. Namely, high medicine prices force certain states to turn to the rationalization of medical treatment. As a result that means that individuals are refused the treatment and the patient's right to health.

The extended protection based on SPC, certainly encourages the research and the development of the pharmaceutical companies. Such research is costly, present high risk and are strictly regulated. SPC is some kind of guarantee and encouragement for such research. However, the professional public is still discussing the profitability of such research and medicine development costs, which surely include the opportunity expenses (Harris, 2017, p. 1). A research has shown that there are cases in which the profit from medicine sale has surpassed the expenses of their research and development on average four years after obtaining the permit to put them into circulation (Prasad \& Mailankody, 2017, p. 1570).

The Supreme Court verdict in the "Santen" case according to which SPC cannot be granted for the products for other medical use should be understood as a balance of interests between the pharmaceutical companies, the manufacturers of the generic medicines and the interests of public health. In that sense the EU Supreme Court decision is awaited with great attention in the case of Novartis (C-354/19). This verdict could to a great extent encourage the reform of the system and the manner in which SPC is granted for medicines.

\section{Lučić Sonja}

Vanredni profesor na Pravnom fakultetu Univerziteta u Kragujevcu, Srbija

\section{SERTIFIKAT O DODATNOJ ZAŠTITI: NEDAVNE ODLUKE SUDA PRAVDE EVROPSKE UNIJE}

REZIME: Poslednjih godina javni zdravstveni sistemi u zemljama sa visokim prihodima su u velikoj meri izloženi pritiscima zbog visokih cena lekova. Na visoke cene lekova utiču tržišni monopoli koje farmaceutske kompanije imaju zahvaljujući patentima, to jest ekskluzivnim pravima koja im se priznaju za lekove. Dodatni faktor koji utiče na visoke cene lekova su 
prošireni oblici zaštite intelektualne svojine, uključujući i produženje roka ekskluzivnosti prava nakon isteka patenta za medicinske proizvode. Sertifikat o dodatnoj zaštiti kao oblik dodatne zaštite za farmaceutske proizvode u Evropskoj uniji reguliše Uredba 469/2009. Ovaj oblik zaštite poznaju i nacionalni propisi o patentima. Od kada je Uredba 469/2009 stupila na snagu raspravlja se pitanje da li sertifikat o dodatnoj zaštiti treba da bude dostupan za nove terapijske primene prethodno odobrenih aktivnih sastojaka. Osim toga, predmet tumačenja bio je i član 3 (a) Uredbe 469/2009, koji zahteva da proizvod, tj. aktivni sastojak ili kombinacija aktivnih sastojaka, koji je predmet prijave sertifikata o dodatnoj zaštiti, bude zaštićen osnovnim patentom. Autor je u radu analizirao nekoliko važnih važnih odluka Suda pravde EU, sa akcentom na nedavne presude u predmetu "Santen" i u predmetu "Royality Pharma". U osnovi ovih slučajeva je dugo raspravljano pitanje o tome koje podsticaje treba dati farmaceutskim kompanijama uključenim u medicinska istraživanja kako bi se podstaklo njihovo ulaganje u nove inovativne tretmane.

Ključne reči: patenti, dodatna zaštita, farmaceutski proizvodi.

\section{References}

1. Bently, L., \& Sherman, B. (2002). Intellectual Property Law, New York: Oxford University Press

2. Fachler, A. (2014). The Need for Reform in Pharmaceutical Protection: The Inapplicability of the Patent System to the Pharmaceutical Industry and the Recommendation of a Shift Towards Regulatory Exclusivitities. Fordham Intellectual Property, Media \& Entertainment Law Journal. 24 (4), pp. 1059-1099

3. Harris, R. (2017). R\&D Costs For Cancer Drugs Are Likely Much Less Than Industry Claims, Study Finds, Washington: NPR

4. Hu, Y., Eynikel, D, Boulet, P., \& Krikorian, G. (2020). Supplementary protection certificates and their impact on access to medicines in Europe: case studies of sofosbuvir, trastuzumab and imatinib, Journal of Pharmaceutical Policy and Practice, 13 (1), pp. 1-12, DOI: 10.1186/ s40545-019-0198-6

5. Kalden, R. (2015). Discussion of recent CJEU case law on SPCs: the three 12 December 2013 cases, Supplementary publication - Official Journal EPO, pp. 120-134 
6. Killick, J., Schultz A., \& Dawes A. (2008). The Stockholm Network Experts' Series on Pharmaceutical Intellectual Property Rights: The special regime of intellectual property for the pharmaceutical industry, Stockholm Network

7. Lasić, I. (2014). Farmaceutski patenti: opšte karakteristike i aktuelna pitanja u međunarodnopravnom kontekstu [Pharmaceutical Patents: general characteristics and current issues in the international context]. Pravni zapisi, 5 (1), pp. 176-196

8. Marković, S. (2016). Da li je okvir patentnog prava postao neodgovarajući za pronalaske lekova? [Has the Patent Law framework become inappropriate for drug inventions?]. In: Marković, M., S., Popović, V. D., (eds.), Aktuelna pitanja prava intelektualne svojine i prava konkurencije: pogled sa Balkana [The current issues of intellectual property law and competition law: a view from the Balkans] (pp. 29-53). Beograd: Pravni fakultet Univerziteta

9. Prasad, V., \& Mailankody, S. (2017). Research and Development spending to bring a single Cancer drug to market and revenues after approval. JAMA Intern Med. 177 (11), pp. 1569-1575

10. Regulation (EC) No 469/2009 of the European Parliament and of the Council of 6 May 2009 concerning the supplementary protection certificate for medicinal products, Official Journal of the European Union, L $152 / 1$ 